ISSN $1978-3000$

\title{
Pengaruh Pengencer Susu Skim dengan Sitrat Kuning Telur dan Lama Penyimpanan terhadap Kualitas Semen Kambing Persilangan Nubian dengan Peranakan Ettawa
}

\author{
Effect of Quality Chilled Semen of Cross Bred Goat (Nubian and Ettawa) \\ which Dilluted with Skim Milk and Yolk Citrate Extender \\ Tatik Suteky, Siwitri Kadarsih dan Yuli Yanti Novitasari \\ Jurusan Peternakan, Fakultas Pertanian Universitas Bengkulu \\ Jalan Raya Kandang Limun, Bengkulu. Telp. (0736) 2170 pst.219.
}

\begin{abstract}
The research was aimed to evaluate the quality chilled semen of cross bred goat (Nubian and Ettawa) which diluted with skim milk and yolk citrate extender in different storage time.. An artivicial vagina was used to collect semen from three mature bucks, after that fresh semen was evaluated. Semen was devided into 5 part and diluted wih 5 combination of extenders ( $\mathrm{P} 1=100 \%$ yolk citrate), (P2 = 75\% yolk citrate $+25 \%$ skim milk), (P3 = $50 \%$ yolk citrate $+50 \%$ skim milk $),(\mathrm{P} 4=25 \%$ yolk citrate $+75 \%$ skim milk $)$ and (P5 $=100 \%$ skim milk), the extended semen was stored for 3,6,9 and 12 days at $4-7^{\circ} \mathrm{C}$. Paramaters measured were $\mathrm{pH}$, sperm motility, live sperm percentage and sperm abnormality percentage. Data were analyzed using SPSS software program. The result showed that $75 \%$ yolk citrate $+25 \%$ skim milk extender could maintain the chilled semen quality at $4-7^{\circ} \mathrm{C}$ until 3 days with 72,79\% live spermatozoa, 2,3 $\pm 0,58$ mass motility, 2,67 $\pm 0,58$ individual motility and 11,49\% abnormal percentage.
\end{abstract}

Key words: Extender, milk skim, yolk citrate, Nubian x PE goat

\begin{abstract}
ABSTRAK
Penelitian ini bertujuan untuk mengevaluasi pengaruh pengencer susu skim dengan sitrat kuning telur dan lama penyimpanan terhadap kualitas semen kambing persilangan Nubian dengan Peranakan Ettawa. Semen ditampung dengan menggunakan vagina buatan dari 3 kambing jantan, setelah ditampung semen segar dievaluasi kemudian diencerkan dengan 5 kombinasi pengencer (P1 = 100\% sitrat kuning telur), (P2 = 75\% sitrat kuning telur $+25 \%$ susu skim $),(\mathrm{P} 3=50 \%$ sitrat kuning telur $+50 \%$ susu skim $),(\mathrm{P} 4=25 \%$ sitrat kuning telur $+75 \%$ susu skim) dan ( $\mathrm{P} 5=100 \%$ susu skim), semen disimpan selama 3, 6, 9 dan 12 hari pada suhu 4-7 ${ }^{\circ} \mathrm{C}$. Kualitas semen ( $\mathrm{pH}$, motilitas spermatozoa, persentase spermatozoa hidup, dan persentase abnormalitas spermatozoa) dihitung setiap 3, 6, 9 dan 12 hari. Hasil penelitian menunjukkan bahwa pengencer terbaik terdapat pada kombinasi pengencer P2 (75\% sitrat kuning telur $+25 \%$ susu skim) pada penyimpanan 3 hari dengan persentase hidup 72,79\%, motilitas massa 2,3 $\pm 0,58$, motilitas individu 2,67 $\pm 0,58$ dan persentase abnormalitas $11,4 \%$.
\end{abstract}

Kata kunci : Pengencer, susu skim, sitrat kuning telur, kambing Nubian x PE.

\section{PEDAHULUAN}

Inseminasi buatan (IB) merupakan salah satu teknologi yang banyak digunakan untuk meningkatkan produksi ternak, memperbaiki mutu genetik dan meningkatkan efisiensi reproduksi (Setioko $d k k$., 2002). Semen yang berkualitas baik, apabila memenuhi kriteria minimal sperma hidup 70\%, motilitas sedang (skor ++) dan abnormalitas maksimal 20\% (Anonimous, 2002).

Semen yang tidak diproses lebih lanjut hanya dapat bertahan tidak lebih dari dua jam setelah diejakulasikan., keadaan ini menjadi 
kendala dalam pelaksanaan inseminasi buatan. Masalah ini dapat diatasi apabila semen ditambahkan dengan suatu bahan pengencer (Trias, 2001). Selain dapat mempertahankan kualitas spermatozoa dalam waktu tertentu, pengencer semen juga dapat meningkatkan volume semen sehingga dapat digunakan untuk mengiseminasikan betina lebih banyak

Bahan-bahan yang digunakan sebagai pengencer semen dapat berasal dari sari buahbuahan, susu, kuning telur atau dari bahanbahan kimia (Affandhy dkk., 1998). Susu skim sebagai salah satu bahan pengencer mengandung protein, glukosa, air dan lemak yang dapat digunakan sebagai sumber energi bagi spermatozoa. Keuntungan lain dari penggunaan susu skim sebagai bahan pengencer adalah susu skim murah murah harganya, mudah didapat serta mudah dalam pengamatan secara visual dalam pengujian kualitas secara mikroskopik karena tidak ada gangguan oleh butir-butir lemak yang jumlahnya terlalu banyak (Toelihere, 1981). Tetapi menurut Utomo dan Sumaryati (2000), susu skim hanya menyediakan zat-zat energi bagi spermatozoa, sehingga perlu ditambahkan dengan bahan lain sebagai penyangga (buffer) dan mencegah terjadinya cold shock.

Salah satu bahan pengencer yang dapat ditambahkan dalam pengencer susu skim adalah sitrat kuning telur, karena sitrat kuning telur mengandung lecitin dan lippoprotein yang dapat digunakan sebagai bahan penyangga (buffer) semen dan mencegah terjadinya cold shock akibat penurunan temperatur yang mendadak (Trias, 2001). Lebih lanjut Junianto dkk. (2000), menyatakan bahwa kuning telur mengandung glukosa yang dapat digunakan sebagai sumber energi bagi spermatozoa (Toelihere, 1981).

\section{MATERI DAN METODE}

\section{Metode Penelitian}

Penelitian ini dilakukan di Lembaga Pengembangan Pertanian Baptis, Bengkulu. Semen ditampung dengan menggunakan vagina buatan dan penampungan dilakukan setiap 3 hari sekali. Segera setelah penampungan dilakukan evaluasi makroskopik dan mikroskopik terhadap semen segar yang meliputi $\mathrm{pH}$, warna, kekentalan, konsentrasi, motilitas massa, motilitas individu, persentase sperma hidup dan persentase abnormal spermatozoa. Semen yang telah memenuhi persyaratan langsung dicampur dengan pengencer susu skim dan sitrat kuning telur sesuai dengan dosis pengenceran

Penelitian ini menggunakan Rancangan Acak Lengkap pola faktorial dengan dua faktor dan tiga ulangan. Faktor pertama yaitu persentase pengencer yang terdiri dari P1 (100\% sitrat kuning telur), P2 (75\% sitrat kuning telur $+25 \%$ susu skim), P3 (50\% sitrat kuning telur $+50 \%$ susu skim), P4 (25\% sitrat kuning telur $+75 \%$ susu skim) dan P5 (100\% susu skim). Faktor kedua yaitu lama penyimpanan pada suhu $4-7 \quad{ }^{\circ} \mathrm{C}$ yang terdiri dari L1 (penyimpanan 3 hari), L2 (penyimpanan 6 hari ), L3 (penyimpanan 9 hari) dan L4 (penyimpanan 12 hari), kemudian disimpan pada suhu 4-7 ${ }^{\circ} \mathrm{C}$ selama 3, 6, 9 dan 12 hari, parameter pengamatan meliputi $\mathrm{pH}$, motilitas massa, motilitas individu, persentase sperma hidup dan persentase abnormalitas spermatozoa.

\section{HASIL DAN PEMBAHASAN}

\section{Karateristik Semen Segar}

Tabel 1. menunjukkan bahwa rata-rata pH semen segar kambing persilangan Nubian dengan Peranakan Ettawa adalah 6,83 \pm 0,29. Hasil ini masih dalam kisaran normal, sesuai dengan pendapat Garner dan Hafez (2000), yang menyatakan bahwa $\mathrm{pH}$ semen kambing dan domba berkisar antara 5,9-7,3. Sedangkan hasil penelitian Yani et al. (2001), menunjukkan bahwa pH semen kambing PE adalah 6,8.

Rata-rata volume semen segar kambing persilangan Nubian dengan Peranakan Ettawa yang diperoleh dari hasil penelitian adalah 1,33 $\pm 0,58 \mathrm{ml}$. Kisaran volume semen kambing ini sesuai dengan pendapat Jainudeen et al. (2000), yang menyebutkan bahwa volume semen kambing yaitu 0,1 - 1,5 ml.

Warna semen kambing yang diperoleh dalam penelitian yaitu putih krem dengan konsistensi kental. Warna semen kambing ini 
Tabel 1. Rata-rata hasil pengamatan semen segar kambing Nubian x PE

\begin{tabular}{ll}
\hline \multicolumn{1}{c}{ Variabel Pengamatan } & Semen Segar \\
\hline $\mathrm{pH}$ & $6,83 \pm 0,29$ \\
Volume & $1,33 \pm 0,58$ \\
Warna & Putih krem \\
Konsistensi & Kental \\
Pergerakan massa & $3 \pm 0$ \\
Pergerakan individu & $3 \pm 0$ \\
Konsentrasi (x 10 /ml) & $3413 \pm 225$ \\
Spermatozoa hidup & $79,87 \pm 1,4$ \\
Abnormalitas spermatozoa & $9,7 \pm 1,54$ \\
\hline
\end{tabular}

dapat dikatakan normal dan sesuai dengan hasil penelitian Herdis dkk. (2005), bahwa warna semen kambing adalah krem. Lebih lanjut Salisbury dkk. (1985), menyatakan bahwa konsistensi adalah kental.

Skor pergerakan massa dan individu spermatozoa semen segar pada kambing penelitian ini adalah $3(+++)$. Pergerakan massa pada skor 3 terlihat dengan adanya gelombang awan hitam, gelap dan tebal yang bergerak cepat seperti menyapu. Pada pergerakan individu diperlihatkan dengan adanya pergerakan spermatozoa yang progresif cepat. Menurut Gordon (1997), sperma yang baik untuk IB adalah sperma yang memiliki pergerakan massa dan individu dengan skor 2 ..

Konsentrasi spermatozoa kambing persilangan Nubian dengan Peranakan Ettawa yang diperoleh dalam penelitian ini dapat dikatakan normal yaitu 3413 juta/ml (Tabel 1), sesuai dengan informasi yang dinyatakan oleh Gordon (1997), bahwa konsentrasi spermatozoa kambing berkisar antara 1500 - 4000 juta/ml.

Persentase spermatozoa hidup dalam semen segar kambing persilangan Nubian dengan Peranakan Ettawa yang diperoleh dari hasil penelitian ini adalah 79,87\% (Tabel 1). Hal ini menunjukkan bahwa persentase spermatozoa hidup yang diperoleh masih dalam keadaan normal. Menurut Hartigan (1995), persentase spermatozoa hidup dalam semen segar yang baik untuk IB minimal 70\%.

Rataan persentase abnormalitas spermatozoa semen segar yang diperoleh dari penelitian ini masih dalam kisaran normal yaitu 9,7 \%. Menurut Bretzlaff (1995),

Tabel 2. Rataan $\mathrm{pH}$ semen kambing Nubian $\mathrm{x}$ PE

\begin{tabular}{|c|c|c|c|c|c|c|}
\hline & \multicolumn{6}{|c|}{ Pengenceran semen } \\
\hline (hari) & P1 & $\mathrm{P} 2$ & P3 & P4 & P5 & Rataan \\
\hline 3 & $7,00 \pm 0,00$ & $6,83 \pm 0,29$ & $7,00 \pm 0,00$ & $6,67 \pm 0,29$ & $6,50 \pm 0,00$ & $6.80 \pm 0.09^{x}$ \\
\hline 6 & $6,50 \pm 0,00$ & $6,50 \pm 0,00$ & $6,50 \pm 0,00$ & $6,50 \pm 0,00$ & $6,33 \pm 0,29$ & $6.50 \pm 0.06^{x}$ \\
\hline 9 & $6,33 \pm 0,29$ & $6,33 \pm 0,29$ & $6,17 \pm 0,29$ & $6,33 \pm 0,29$ & $6,00 \pm 0,00$ & $6,23, \pm 0,19^{n}$ \\
\hline 12 & $6,33 \pm 0,29$ & $6,33 \pm 0,29$ & $6,17 \pm 0,29$ & $6,17 \pm 0,29$ & $6,00 \pm 0,01$ & $6,20, \pm 0,26^{2}$ \\
\hline Rataan & $6,54 \pm 0,15^{a}$ & $6,50 \pm 0,22^{a}$ & $6,46 \pm 0,15^{2}$ & $6,42+0,22^{2}$ & $6,21 \pm 0,07^{b}$ & \\
\hline Interaksi & & & & & & $\mathrm{ns}$ \\
\hline
\end{tabular}

Keterangan : Superskrip yang berbeda pada baris yang sama menunjukkan perbedaan nyata $(\mathrm{P}<0,05)$, sedangkan superskrip pada kolom yang sama menunjukkan perbedaan sangat nyata $(\mathrm{P} \varangle 0,01)$. ns $=$ Berbeda tidak nyata 
persentase abnormalitas spermatozoa semen segar yang baik untuk inseminasi buatan tidak lebih dari $20 \%$.

Berdasarkan nilai karakteristik semen segar yang diperoleh maka dapat diketahui bahwa semen segar kambing persilangan Nubian dengan Peranakan Ettawa mempunyai kualitas semen yang baik, dan dapat diproses lebih lanjut dalam bentuk semen cair dengan menggunakan pengencer semen.

Hasil analisis ragam menunjukkan bahwa tidak terdapat interaksi $(\mathrm{P}>0,05)$ antara persentase pengencer dan lama penyimpanan. Hasil analisis ragam menunjukkan bahwa persentase pengencer berpengaruh nyata $(\mathrm{P}<0,05)$ terhadap $\mathrm{pH}$ semen. Hasil Uji lanjut DMRT menunjukkan $\mathrm{pH}$ semen P1 berbeda tidak nyata $(\mathrm{P}>0,05)$ dengan $\mathrm{P} 2, \mathrm{P} 3$ dan $\mathrm{P} 4$ tetapi berbeda nyata $(\mathrm{P}<0,05)$ dengan $\mathrm{P}$. $\mathrm{pH}$ semen menurun dengan meningkatnya penggunaan pengencer susu skim dan menurunnya penggunaan pengencer sitrat kuning telur. Menurut Utomo dan Sumaryati (2000), pengencer susu skim tidak mengandung larutan penyangga yang dapat mempertahankan $\mathrm{pH}$ akibat dari meningkatnya asam laktat karena adanya aktivitas metabolisme spermatozoa. Pendapat ini diperkuat oleh Toelihere (1981), yang menyatakan bahwa dalam keadaan anaerobik metabolisme sperma dapat menghasilkan asam laktat yang dapat menurunkan $\mathrm{pH}$ semen.
Tabel 2. menunjukkan bahwa semakin lama penyimpanan maka $\mathrm{pH}$ semen semakin rendah. Hasil analisis ragam pada lama penyimpanan berpengaruh sangat nyata $(\mathrm{P}<0,01)$ terhadap $\mathrm{pH}$ semen, dan uji DMRT menunjukkan bahwa rata-rata $\mathrm{pH}$ semen yang disimpan selama 3 hari (L1) berbeda sangat nyata $(\mathrm{P}<0,01)$ dengan penyimpanan 6 hari (L2), 9 hari (L3) dan 12 hari (L4). Sedangkan penyimpanan 6 hari (L2) berbeda sangat nyata $(\mathrm{P}<0,01)$ dengan penyimpanan 9 hari (L3) dan 12 hari (L4). Tetapi penyimpanan 9 hari (L3) tidak berbeda nyata $(\mathrm{P}>0,05)$ dengan penyimpanan 12 hari (L4). Penurunan $\mathrm{pH}$ semen ini terjadi karena semakin lama waktu penyimpanan semen maka nutrisi yang terdapat dalam bahan pengencer akan semakin berkurang dan hasil metabolisme anaerobik yang berupa asam laktat akan semakin tinggi, sehingga $\mathrm{pH}$ semen akan semakin rendah. Pernyataan ini diperkuat oleh hasil penelitian Utomo dan Sumaryati (2000), dimana $\mathrm{pH}$ semen kambing dan domba yang disimpan selama 72 jam dalam pengencer susu skim menurun menjadi 4,92.

\section{Pengamatan Uji Mikroskopik}

Hasil analisis ragam menunjukkan bahwa tidak terdapat interaksi $(\mathrm{P}>0,05)$ antara persentase pengencer dan lama penyimpanan, tetapi persentase pengencer berpengaruh nyata $(\mathrm{P}<0,05)$ terhadap skor pergerakan massa spermatozoa (Tabel 3). Uji lanjut DMRT

Tabel 3. Rataan skor pergerakan massa spermatozoa kambing Nubian x PE

\begin{tabular}{llccccc}
\hline $\begin{array}{l}\text { Lama } \\
\text { Penyimpanan }\end{array}$ & \multicolumn{7}{c}{ Pengenceran semen } \\
\hline (hari) & \multicolumn{1}{c}{ P1 } & P2 & P3 & P4 & P5 & Rataan \\
\hline 3 & $2,00 \pm 0,00$ & $2,33 \pm 0,58$ & $2,00 \pm 0,00$ & $2,00 \pm 0,00$ & $2,00 \pm 0,00$ & $2,07 \pm 0,14^{\mathrm{a}}$ \\
6 & $1,00 \pm 0,058$ & $1,00 \pm 0,00$ & $1,00 \pm 0,00$ & $1,00 \pm 0,00$ & $1,00 \pm 0,00$ & $1,00 \pm 0,00$ \\
9 & $0,00 \pm 0,00$ & $0,33 \pm 0,58$ & $0,00 \pm 0,00$ & $0,00 \pm 0,00$ & $0,00 \pm 0,00$ & $0,07 \pm 0,12^{\mathrm{c}}$ \\
12 & $0,00 \pm 0,00$ & $0,00 \pm 0,00$ & $0,00 \pm 0,00$ & $0,00 \pm 0,00$ & $0,00 \pm 0,00$ & $0,00 \pm 0,00$ \\
\hline Rataan & $0,75 \pm 0,00^{\mathrm{b}}$ & $0,92 \pm 0,32^{\mathrm{a}}$ & $0,75 \pm 0,00^{\mathrm{b}}$ & $0,75 \pm 0,00^{\mathrm{b}}$ & $0,75 \pm 0,00^{\mathrm{b}}$ & \\
\hline Interaksi & & & & & & $\mathrm{ns}$ \\
\hline
\end{tabular}

Keterangan : Superskrip yang berbeda pada baris yang sama menunjukkan berbeda nyata $(\mathrm{P}<0,05)$, sedangkan superskrip yang berbeda pada kolom yang sama menunjukkan perbedaan sangat nyata $(\mathrm{P}<0,01)$. ns = Berbeda tidak nyata $(\mathrm{P}>0,05$ 
menunjukkan bahwa pergerakan massa spermatozoa pada P1 berbeda tidak nyata $(\mathrm{P}>0,05)$ dengan P3, P4 dan P5 tetapi berbeda nyata $(\mathrm{P}<0,05)$ dengan $\mathrm{P} 2$. Hal ini terjadi karena adanya perbedaan nutrisi yang terkandung dalam bahan pengencer. Menurut Utomo dan Sumaryati (2000), pengencer susu skim tidak terdapat larutan penyangga yang dapat mempertahankan $\mathrm{pH}$. Sedangkan pada
(P1) berbeda tidak nyata dengan (P3), (P4) dan (P5) tetapi berbeda nyata $(\mathrm{P}<0,05)$ dengan $(\mathrm{P} 2)$. Hal ini terjadi karena adanya perbedaan nutrisi yang terkandung dalam bahan pengencer. Menurut Utomo dan Sumaryati (2000), bahwa dalam pengencer susu skim hanya menyediakan zat energi, sedangkan pengencer sitrat kuning telur terdapat larutan penyangga dan anti cold shock (Trias, 2001).

Semakin lama penyimpanan semen

Tabel 4. Rataan skor motilitas individu spermatozoa kambing Nubian x PE

\begin{tabular}{l|c|c|c|c|c|c|}
\hline \multirow{2}{*}{$\begin{array}{l}\text { Lama } \\
\text { Penyimpanan }\end{array}$} & \multicolumn{7}{|c|}{ Pengenceran semen } \\
\hline (hari) & P1 & P2 & P3 & P4 & P5 & Rataan \\
\hline 3 & $2,00 \pm 0,00$ & $2,67 \pm 0,58$ & $2,33 \pm 0,58$ & $2,00 \pm 0,00$ & $2,00 \pm 0,00$ & $2,20 \pm 0,23 \mathrm{a}$ \\
\hline 6 & $1,33 \pm 0,58$ & $1,67 \pm 0,58$ & $1,00 \pm 0,00$ & $1,00 \pm 0,00$ & $1,33 \pm 0,58$ & $1,27 \pm 0,35 \mathrm{~b}$ \\
\hline 9 & $0,00 \pm 0,00$ & $0,33 \pm 0,58$ & $0,33 \pm 0,58$ & $0,00 \pm 0,00$ & $0,00 \pm 0,00$ & $1,13 \pm 0,23 \mathrm{c}$ \\
\hline 12 & $0,00 \pm 0,00$ & $0,00 \pm 0,00$ & $0,00 \pm 0,00$ & $0,00 \pm 0,00$ & $0,00 \pm 0,00$ & $0,00 \pm 0,00$ \\
\hline Rataan & $0,83 \pm 0,15^{\mathrm{b}}$ & $1,17 \pm 0,44^{\mathrm{a}}$ & $0,92 \pm 0,29^{\mathrm{b}}$ & $0,75 \pm 0,00^{\mathrm{b}}$ & $0,83 \pm 0,15^{\mathrm{b}}$ & \\
\hline Interaksi & & & & & & ns \\
\hline
\end{tabular}

Keterangan : Superskrip yang berbeda pada baris yang sama menunjukkan perbedaan nyata $(\mathrm{P}<0,05)$, sedangkan superskrip yang berbeda pada kolom yang sama menunjukkan perbedaan sangat nyata $(\mathrm{P}<0,01)$. ns $=$ Berbeda tidak nyata $(\mathrm{P}>0,05$

pengencer sitrat kuning telur mengandung lecitin dan lipoprotein yang dapat mencegah terjadinya cold shock (Trias, 2001).

Analisis ragam lama penyimpanan terhadap skor pergerakan massa berpengaruh sangat nyata $(\mathrm{P}<0,01)$. Uji lanjut DMRT menunjukkan bahwa lama penyimpanan 3 hari (L1) berbeda sangat nyata $(\mathrm{P}<0,01)$ dengan lama penyimpanan 6 hari (L2), 9 hari (L3) dan 12 hari (L4) tetapi lama penyimpanan 9 hari (L3) tidak berbeda nyata $(\mathrm{P}>0,05)$ dengan lama penyimpanan 12 hari (L4). Rata-rata skor pergerakan massa spermatozoa mengalami penurunan selama penyimpanan. Hal ini sesuai dengan pendapat Utomo dan Sumaryati (2000), bahwa semakin lama waktu penyimpanan maka nutrisi yang terdapat dalam bahan pengencer akan semakin menurun dan dapat menurunkan motilitas spermatozoa. Lebih lanjut Salisbury dkk. (1985), menyatakan bahwa penurunan motilitas spermatozoa dapat disebabkan karena terjadinya penurunan $\mathrm{pH}$ dan cold shock selama penyimpanan.

\section{Motilitas Individu Spermatozoa}

Hasil analisis ragam menunjukkan bahwa tidak terdapat interaksi $(\mathrm{P}>0,05)$ antara persentase pengencer dan lama penyimpanan (Tabel 4). Hasil uji lanjut DMRT menunjukkan bahwa pergerakan individu spermatozoa pada menyebabkan penurunan pergerakan individu, dan lama penyimpanan berpengaruh sangat nyata $(\mathrm{P}<0,01)$ terhadap skor pergerakan individu spermatozoa. Hasil uji lanjut DMRT menunjukkan bahwa skor pergerakan individu pada penyimpanan 3 hari (L1) berbeda sangat nyata $(\mathrm{P}<0,01)$ dengan lama penyimpanan 6 hari (L2), 9 hari (L3) dan 12 hari (L4) tetapi lama penyimpanan 9 hari (L3) tidak berbeda nyata $(\mathrm{P}>0,05)$ dengan lama penyimpanan 12 hari (L4). Rata-rata skor pergerakan individu spermatozoa mengalami penurunan selama penyimpanan. Hal ini sesuai dengan pendapat Utomo dan Sumaryati (2000), bahwa semakin lama waktu penyimpanan maka nutrisi yang terdapat dalam bahan pengencer akan semakin menurun dan dapat menurunkan motilitas spermatozoa.

\section{Persentase Spermatozoa Hidup}

Hasil analisis ragam menunjukkan bahwa interaksi persentase pengencer dan lama penyimpanan semen terhadap persentase spermatozoa hidup berpengaruh sangat nyata $(\mathrm{P}<0,01)$ sebagaimana terlihat pada Tabel 5 . Persentase spermatozoa hidup tertinggi $(72,79$ 
ISSN $1978-3000$

Tabel 5. Rataan persentase spermatozoa hidup semen kambing Nubian x PE

\begin{tabular}{|c|c|c|c|c|c|c|}
\hline \multirow{2}{*}{$\begin{array}{l}\text { Lama } \\
\text { Penyimpanan }\end{array}$} & \multicolumn{7}{|c|}{ Pengenceran semen } \\
\hline (hari) & P1 & P2 & P3 & P4 & P5 & Rataan \\
\hline 3 & $71,25 \pm 0,94^{\mathrm{a}}$ & $72,79 \pm 1,51^{\mathrm{a}}$ & $72,61 \pm 1,07^{\mathrm{a}}$ & $72,15 \pm 0,26^{\mathrm{a}}$ & $70,50 \pm 0,50^{\mathrm{a}}$ & $71,86 \pm 0,86^{\mathrm{a}}$ \\
\hline 6 & $61,54 \pm 0,84^{\mathrm{c}}$ & $65,18 \pm 1,90^{\mathrm{b}}$ & $63,58 \pm 0,72 \mathrm{~b}^{\mathrm{c}}$ & $63,31 \pm 1,65^{\mathrm{bc}}$ & $61,52 \pm 1,16^{\mathrm{c}}$ & $6303 \pm 0,25^{\mathrm{c}}$ \\
\hline 9 & $27,76 \pm 2,45^{\mathrm{i}}$ & $34,29 \pm 0,83^{\mathrm{a}}$ & $34,17 \pm 0,76^{\mathrm{a}}$ & $30,52+2,26^{\mathrm{c}}$ & $21,80 \pm 0,75^{\mathrm{h}}$ & $29,71 \pm 1,41^{\mathrm{a}}$ \\
\hline 12 & $19,65 \pm 1,38^{\mathrm{hi}}$ & $26,42+1,29^{\mathrm{ag}}$ & $24,68 \pm 0,36^{\mathrm{g}}$ & $24,90 \pm 1,83^{\mathrm{g}}$ & $18,83 \pm 1,97^{\mathrm{i}}$ & $22,90 \pm 1,37^{\mathrm{a}}$ \\
\hline Interaksi & & & & & & $* * *$ \\
\hline
\end{tabular}

Keterangan : Superskrip yang berbeda pada baris dan kolom yang berbeda menunjukkan perbedaan sangat nyata $(\mathrm{P}<0,01),{ }^{* * *}=$ Berpengaruh sangat nyata $(\mathrm{P}<0,01), \mathrm{P} 1=100 \%$ Sitrat Kuning Telur $+0 \%$ Susu Skim, P2 $=75 \%$ Sitrat Kuning Telur $+25 \%$ Susu Skim, P3 $=50 \%$ Sitrat Kuning Telur $+50 \%$ Susu Skim, P4 $=$ $25 \%$ Sitrat Kuning Telur $+50 \%$ Susu Skim, P5 =0 \% Sitrat Kuning Telur $+100 \%$ Susu Skim.

\%) terdapat pada P2 dengan lama penyimpanan 3 hari (L1), sedangkan persentase spermatozoa hidup terendah $(18,83 \%)$ terdapat pada P5 dengan lama penyimpanan 12 hari (L4). Bila dibandingkan dengan persentase spermatozoa hidup dalam keadaan segar $(79,87$ $\%)$, maka persentase pengencer dan lama penyimpanan menyebabkan penurunan persentase spermatozoa hidup. Hal disebabkan karena nutrisi yang terkandung dalam bahan pengencer semakin berkurang dengan bertambahnya waktu penyimpanan sehingga persentase spermatozoa hidup yang dihasilkan juga menurun. Hal ini sesuai dengan pendapat Utomo dan Sumaryati (2000), bahwa lama waktu penyimpanan sangat mempengaruhi kualitas sperma, semakin lama waktu penyimpanan maka nutrisi yang terdapat dalam bahan pengencer akan semakin menurun.

Persentase spermatozoa hidup semakin menurun dengan meningkatnya penggunaan bahan pengencer susu skim. Hal ini disebabkan didalam bahan pengencer susu skim tidak mengandung lipoprotein dan lechitin yang berfungsi sebagai anti cold shock dan penyangga pH (Utomo dan Sumaryati, 2000). Menurut Yuliyanti (2001), gizi yang terkandung dalam sitrat kuning telur lebih baik dari susu skim sehingga mampu memenuhi kebutuhan hidup

Tabel 6. Rataan hasil pengamatan abnormalitas spermatozoa semen kambing Nubian x PE

\begin{tabular}{|c|c|c|c|c|c|c|}
\hline \multirow{2}{*}{$\begin{array}{l}\text { Lama } \\
\text { Penyimpanan } \\
\text { (hari) }\end{array}$} & \multicolumn{6}{|c|}{ Pengenceran semen } \\
\hline & P1 & $\mathrm{P} 2$ & P3 & P4 & P5 & Rataan \\
\hline 3 & $11,13 \pm 1,20$ & $11,49 \pm 0,50$ & $11,63 \pm 1,31$ & $11,73 \pm 0,94$ & $11,49 \pm 1,36$ & $11,49 \pm 1,06^{\mathrm{d}}$ \\
\hline 6 & $14,40 \pm 0,11$ & $15,47 \pm 0,68$ & $14,73 \pm 2,34$ & $11,73 \pm 0,94$ & $14,34 \pm 1,0$ & $14,13 \pm 1,02^{c}$ \\
\hline 9 & $16,75 \pm 2,04$ & $18,17 \pm 1,27$ & $16,83 \pm 1,20$ & $16,42+1,46$ & $16,71 \pm 1,07$ & $16,98 \pm 1,41^{b}$ \\
\hline 12 & $24,19 \pm 0,70$ & $22,41 \pm 2,27$ & $25,15 \pm 2,49$ & $23,35 \pm 2,06$ & $24,03 \pm 2,26 a$ & $24,03 \pm 2,26^{\pi}$ \\
\hline Rataan & $16,62+0,01^{2}$ & $16,89 \pm 1,18^{\pi}$ & $17,09 \pm 1,84^{\pi}$ & $16,23 \pm 1,79^{\pi}$ & $16,47 \pm 1,38^{\pi}$ & \\
\hline Interaksi & & & & & & ns \\
\hline
\end{tabular}

Keterangan : Superskrip yang sama pada baris yang sama menunjukkan berbeda tidak nyata $(P>0,05)$, sedangkan superskrip yang berbeda pada kolom yang sama menunjukkan perbedaan sangat nyata $(\mathrm{P}<0,01)$, ns $=$ Berbeda tidak nyata $(\mathrm{P}>0,05), \mathrm{P} 1=100 \%$ Sitrat Kuning Telur $+0 \%$ Susu Skim, P2 $=75 \%$ Sitrat Kuning Telur $+25 \%$ Susu Skim, P3 $=50 \%$ Sitrat Kuning Telur + 50\% Susu Skim, P4 = $25 \%$ Sitrat Kuning Telur + 50\% Susu Skim, P5 = 0 \% Sitrat Kuning Telur + 100\% Susu Skim. 
spermatozoa selama waktu penyimpanan.

Lama penyimpanan berpengaruh sangat nyata $(\mathrm{P}<0,01)$ terhadap persentase spermatozoa hidup. Hasil uji lanjut DMRT menunjukkan bahwa persentase spermatozoa hidup yang disimpan 3 hari (L1) berbeda sangat nyata $(P<0,01)$ dengan penyimpanan 6 hari (L2), 9 hari (L3) dan 12 hari (L4) pada pengencer P1, P2, P3, P4 dan P5. Menurut Salisbury dkk. (1985), bahwa kualitas spermatozoa selama penyimpanan mengalami penurunan yang disebabkan karena cold shock, perubahan $\mathrm{pH}$ dan berkurangnya nutrisi yang terkandung dalam bahan pengencer.

\section{Persentase Abnormalitas Spermatozoa}

Hasil analisis ragam menunjukkan bahwa tidak terdapat interaksi $(\mathrm{P}>0,05)$ antara persentase pengencer dan lama penyimpanan. Persentase abnormalitas semakin tinggi dengan bertambahnya waktu penyimpanan. Hal ini menunjukkan bahwa lama penyimpanan berpengaruh sangat nyata $(\mathrm{P}<0,01)$ terhadap persentase abnormalitas spermatozoa. Hasil uji lanjut DMRT menunjukkan bahwa persentase abnormalitas pada penyimpanan 12 hari (L4) berbeda sangat nyata $(\mathrm{P}<0,01)$ dengan 9 hari (L3), 6 hari (L2) dan 3 hari (L3). Hal ini sebabkan oleh pengaruh penurunan $\mathrm{pH}$ semen, tekanan osmotik dan stres dingin yang terjadi selama penyimpanan. Sesuai dengan pendapat Salisbury dkk. (1985), bahwa cold shock dan perubahan tekanan osmotik terhadap spermatozoa yang diejakulasikan menyebabkan perubahan pembentukan spermatozoa yang dapat menyebabkan abnormalitas. Lebih lanjut Hafez (2000), menyatakan bahwa meningkatnya tahapan selama penyimpanan dengan diikuti penurunan suhu secara cepat akan meningkatkan persentase abnormalitas spermatozoa.

\section{SIMPULAN}

Penggunaan pengencer susu skim dan sitrat kuning telur dapat mempertahankan kualitas semen kambing persilangan Nubian dengan peranakan Ettawa selama tiga hari. Kualitas terbaik terdapat pada kombinasi pengencer $25 \%$ susu skim dan $75 \%$ sitrat kuning telur dengan persentase hidup 72,79\%, motilitas massa 2,33 $\pm 0,58$, motilitas individu $2,67 \pm 0,58$ dan persentase abnormalitas 11,49 $\%$.

\section{DAFTAR PUSTAKA}

Affandhy, L., U. Umiyasih, dan K. Maksu'm. 1998. Evaluasi kualitas semen beku sapi Madura dengan berbagai diluter dan kandungan kuning telur yang berbeda. Hlm: 233-239. Proseding Seminar Nasional Teknologi Peternakan dan Veteriner. Ciawi-Bogor.

Anonimous. 2002. Diktat Pelatihan Petugas Desentralisasi Balai Inseminasi Buatan (Bull Master dan Laboran). Balai Inseminasi Buatan. Lembang.

Ax, R. L., M. R. Dally, B. A Didion, R. W. Lenz, C. C. Love, D. D. D. Arner, B. Hafez and M. E. Bellin. 2000. Semen Evaluation. p. 365-367. in Hafez, B and E. S. E. Hafez (eds) Reproduction in Farm Animal. 7 th ed. Lippincott \& Wilkins, Philadelphia.

Brezlaff, K. 1995. Goat Breeding and Infertility. p. 169-207. in. J. Meredith (eds). Animal Breeding and Infertility. Blackweel Science Ltd. Victoria, Australia.

Garner, D. L and E. S. E. Hafez. 2000. Spermatozoa and Seminal Plasma. P. 96109. in Hafez, B and E. S. E. Hafez (eds) Reproduction in Farm Animal. 7 th ed. Lippincott \& Wilkins, Philadelphia.

Gordon, I. 1997. Controlled Reproduction in Sheep and Goat. CABI Publising. Cambridge. USA.

Hafez, B. 2000. Technique for Determining Spermatozoa Concentration Using a Haemocytometer. p. 481-495. in Hafez, B and E.S.E. Hafez (eds). Reproduction in Farm Animal. 7 th ed. Lippincott \& Wilkins, Philadelphia.

Hartigan, P. J. 1995. Cattle Breeding and Infertility. p. 86-168. in. J. Meredith (eds). Animal Breeding and Infertility. Blackweel Science Ltd. Victoria, Australia.

Herdis, M. Rizal, A. Boediono, R.I. Arifiantini, T. Saili, A.S. Aku, dan Yulnawati. 2005. Optimasi kualitas semen beku domba Garut melalui penambahan trehalosa ke 
dalam pengencer kuning telur. Jurnal Indonesia Tropic Animal Agriculture 30(4):229-236.

Hunter, R. H. F. 1995. Fisiologi dan Teknologi Reproduksi Hewan Betina Domestik. ITB, Bandung.

Jainudeen, M. R., Wahid and E. S. E. Hafez. 2000. Sheep and Goat. p. 172-181. in Hafez, B and E. S. E. Hafez (eds). Reproduction in Farm Animal. $7^{\text {th }}$ ed. Lippincott \& Wilkins, Philadelphia.

Junianto, L., B. Sutiono, S. Kismiati. 2000. Pengaruh pengencer semen dengan berbagai kuning telur unggas terhadap motilitas dan daya hidup sperma ayam Kampung. Jurnal Tropical Animal 2:30-34.

Salisbury, G. W., N. L. Vandermark., dan R. Djanuar. 1985. Fisiologi Reproduksi dan Inseminasi Buatan pada Sapi. Gadjah Mada University Press, Yogyakarta.

Setioko, A. R., P. Situmorang, D. A. Kusumaningrum, T. Sugiarti, E. Triwulaningsih dan R. G. Sianturi. 2002. Pengaruh frekuensi penampungan semen itik dan entok terhadap kualitas sperma sebelum dan sesudah dibekukan. Hlm:
309-312. Proseding Seminar Nasional Teknologi Peternakan dan Veteriner. Ciawi-Bogor.

Toelihere, M. 1981. Inseminasi Buatan pada Ternak. Angkasa, Bandung.

Trias, P. A. H. 2001. Kualitas sperma dan pengaruh bahan pengencer terhadap daya hidup spermatozoa domba lokal. Buletin Pertanian dan Peternakan 2(3):14-20.

Utomo, S dan Sumaryati. 2000. Pengaruh suhu penyimpanan $5^{0} \mathrm{c}$ terhadap sperma kambing dan domba dengan pengencer susu skim. Buletin Pertanian dan Peternakan 8 (2):70-79.

Yani, A., Nuryadi dan Pratiwi. 2001. Pengaruh tingkat substitusi santan kelapa pada pengencer tris dan waktu penyimpanan terhadap kualitas semen kambing Peranakan Ettawa (PE), http: //www.geoogle.com/digilib.brawijaya.ac.i d/html.28 Februari 2007.

Yulianti, F. 2001. Pengaruh berbagai media pengencer terhadap kualitas semen kalkun lokal. Srkipsi. Fakultas Pertanian. Universitas Lampung, Lampung. 